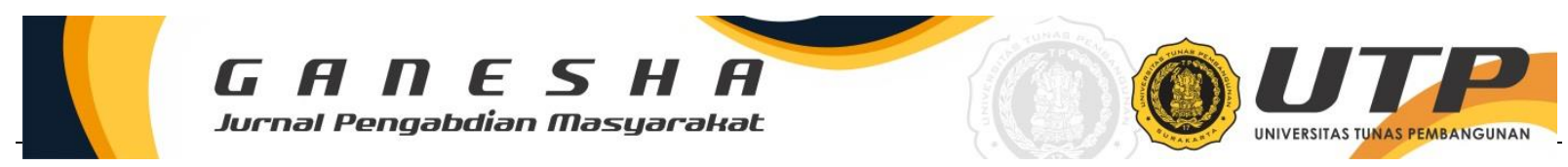

\title{
PENDAMPINGAN PERENCANAKAN RENOVASI MASJID NURRULLOH DUA LANTAI UNTUK MENINGKATKAN KAPASITAS JAMAAH
}

\author{
Tri Hartanto*1, A Bambang Yuono ${ }^{2}$ \\ 1,2, Universitas Tunas Pembangunan Surakarta \\ *e-mail: tri.hartanto@lecture.utp.ac.id
}

\begin{abstract}
Abstrak
Pendampingan perencanaan pembangunan renovasi Masjid Nurrulloh dilaksanakan untuk membantu masyarakat di lingkungan kampung Ngemplak RT.02 RW.29 Mojosonga, Jebres, Surakarta. Renovasi pembangunan masjid di lingkungan kampung Ngemplak ini dilakukan karena kapasitas masjid yang sudah tidak bisa menampung jamaah, khususnya pada waktu ibadah sholat Jum'at dan ibadah Romadhlon. Kesulitan yang dialami oleh masyarakat kampung Ngemplak didalam perencanaan masjid adalah bagaimana membuat desain masjid yang baik secara arsitektural dan fungsional, bagaimana merencanakan dan menghitung kekuatan strukturnya dan bagaimana perhitungan biayanya untuk pembangunannya. Sehingga keberadaan tim pengabdian masyarakat dari program studi Arsitektur dan Teknik Sipil Universitas Tunas Pembangunan (UTP) Surakarta, diharapkan mampu merencanakan desain Masjid Nurrulloh. Dengan desain perencanaan dan perencangan yang baik secara arsitektural, diharapkan masjid ini akan menjadi kebanggaan warganya dan akan dapat menumbuhkan kembangkan kegiatan keagamaan bagi seluruh warganya. Tim pengabdian telah mendampingi didalam perencanaan Gambar dan RAB masjid Nurrulloh yang direncanakan menjadi dua lantai. Tahap berikutnya adalah terkait pelaksanaan renovasi, yang membutuhkan dana \pm Rp. 1.500.000.000,00. Adapun biaya/dana renovasi masjid yang akan dilaksanakan bersumber dari swadaya masyarakat setempat. Takmir Masjid berencana menghimpun dana, dengan membuat proposal bantuan dana kepada semua masyarakat kampung Ngemplak RT.02 RW.29 Mojosongo, Surakarta. Selain warga setempat, penggalangan dana juga akan disampaikan kepada semua kaum Muslimin di kota Surakarta dan sekitarnya. Harapanya dana yang ada sekarang ditambah dengan hasil penggalangan dana, pembangunan masjid segera terealisasi. Kehadiran tim pengabdian yang telah menghasilkan gambar kerja dan perhitungan RAB akan sangat berguna untuk perijinan pembangunan dan penggalangan dana.
\end{abstract}

Kata kunci: pendampingan, perencanaan, renovasi, masjid Nurrulloh

\begin{abstract}
Assistance in planning the renovation of the Nurrulloh Mosque was carried out to help the community in the Ngemplak village environment RT.02 RW.29 Mojosonga, Jebres, Surakarta. The renovation of the mosque construction in the Ngemplak village environment was carried out because the capacity of the mosque was no longer able to accommodate worshipers, especially during Friday prayers and Ramadan worship. The difficulties experienced by the people of Ngemplak village in planning the mosque are how to design a good mosque architecturally and functionally, how to plan and calculate the strength of its structure and how to calculate the cost for its construction. So that the existence of a community service team from the Architecture and Civil Engineering study program, Tunas Pembangunan of Univercity (UTP) Surakarta, is expected to be able to plan the design of the Nurrulloh Mosque. With good planning and architectural design, it is hoped that this mosque will become the pride of its citizens and will be able to foster religious activities for all its citizens. The service team has assisted in planning the Drawings and Budget and Cost Plan (RAB) of the Nurrulloh mosque which is planned to be two floors. The next stage is related to the renovation, which requires funds of \pm Rp. 1,500,000,000.00. The costs/funds for the renovation of the mosque to be carried out are sourced from local non-governmental organizations. Takmir Masjid plans to raise funds, by making a proposal for financial assistance to all residents of Ngemplak village RT.02 RW.29 Mojosongo, Surakarta. In addition to local residents, fundraising will also be conveyed to all Muslims in the city of Surakarta and its surroundings. It is hoped that the existing funds, coupled with the results of fundraising, will soon realize the construction of a mosque. The presence of a service team that has produced working drawings and $R A B$ calculations will be very useful for development permits and fundraising.
\end{abstract}

Keywords: Assistance, planning, renovation, Nurrulloh mosque 


\section{PENDAHULUAN}

Kampung Ngemplak Ngemplak RT.02 RW.29 Mojosonga, Jebres, Surakarta berada di tengah-tengah permukiman RW.29. Kampung ini berada di sisi utara sungai Kali Anyar dan dihubungkan jembatan biru yang memiliki akses ke pintu gerbang utara kampus UNS Surakarta. Sehingga masyarakat kampung Ngemplak, selain warga asli, juga terdapat warga lajo/anak-anak kost mahasiswa UNS Surakarta. Sehingga kawasan kampung ini cukpu ramai dan padat. Juga masyarakat sekitar yang berada di RW.29 yang sangat dekat dengan lokasi masjid cukup banyak. Sehingga masjid ini semakin banyak jamaahnya.

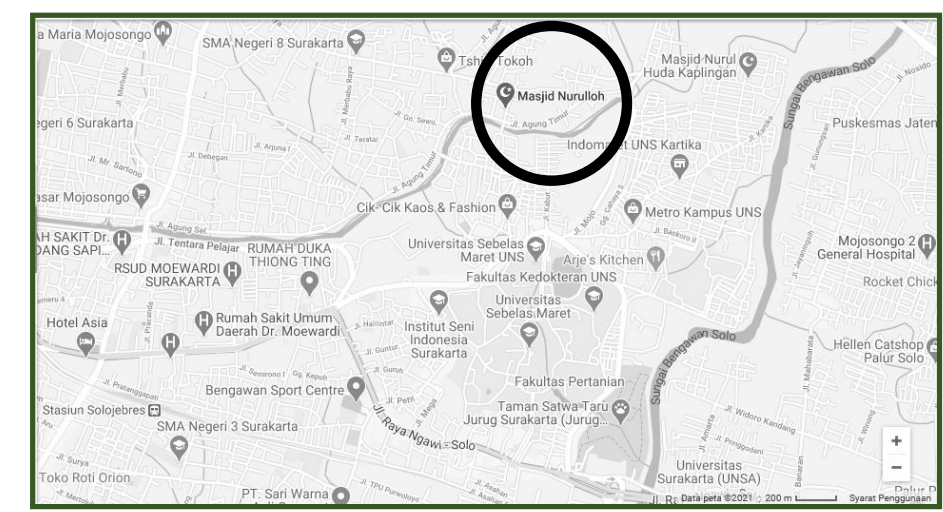

Gambar 1. Lokasi Masjid Nurulloh, di Mojosongo, Jebres, Kota Surakarta

Saat ini lingkungan kampung Ngemplak RT.02 RW.29 telah memiliki fasilitas masjid namun kondisinya sudah kurang memadai dari kapasitas jamaah yang kian hari semakin meningkat jumlahnya, sehingga warga berkeinginan untuk merenovasi bangunan masjid. Selain itu secara fisik bangunan masjid yang sudah ada saat ini sangat sederhana, belum terencana dengan baik, dan sejalan perkembangan lingkungan, bentuk masjid sudah kurang representatif lagi. Kondisi fisik bagian luar juga sudah mulai rusak. Karena keterbatasan lahan maka masjid Nurulloh direncanakan untuk renovasi menjadi dua lantai.

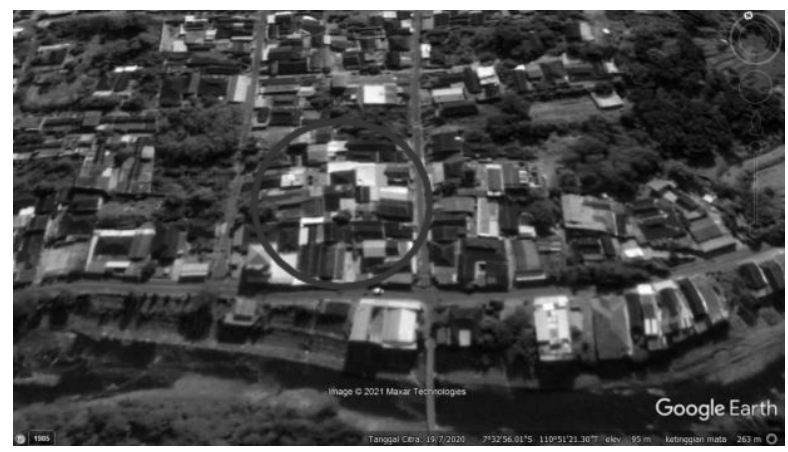

Gambar 2. Letak Masjid Nurulloh berada di kampung Ngemplak RT.02 RW.29

Letak masjid Nurulloh, berada di tengah-tengah permukiman masyarakat Ngemplak RT.02 RW.29 Kelurahan Mojosongo, Jebres, Surakarta. Kondisi lingkungan yang sangat padat, pengembangan masjid ini hanya bisa dilakukan ke arah vertikal/bertingkat. Letaknya yang strategis membuat masjid ini banyak didatangi pula oleh orang yang dalam perjalanan. 


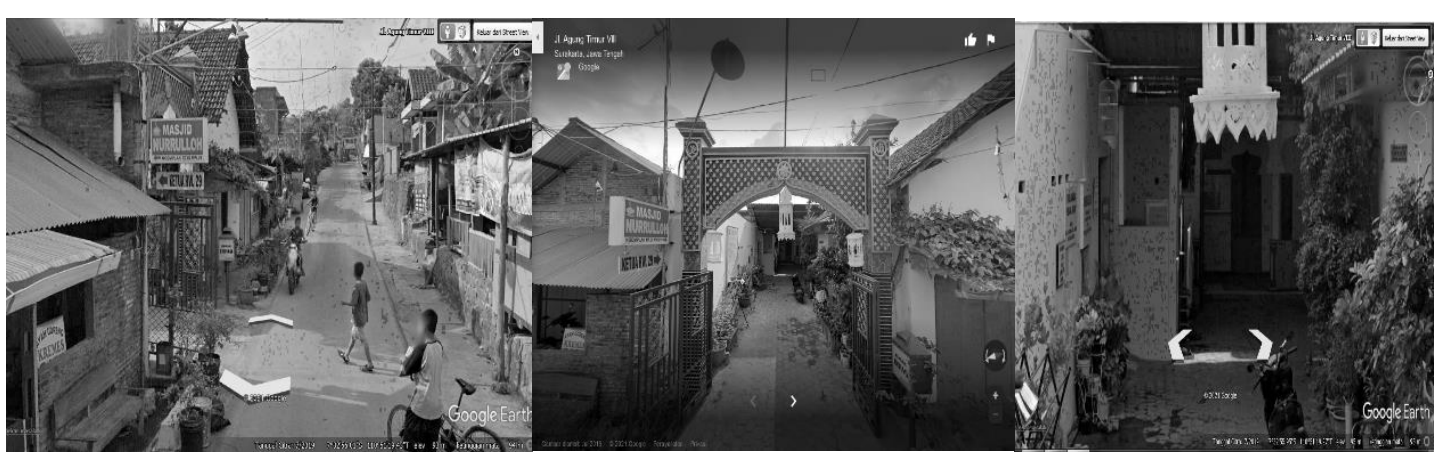

Gambar 3. Suasana, Jalan/akses ke masjid Nurulloh

Dari gambaran kondisi yang telah disampaikan, maka untuk renovasi masjid Nurrulloh perlu adanya pendampingan dalam proses perencanaan, sehingga efisiensi biaya dapat diminimalkan, namun dari segi fungsi dan kapasitas bangunan masjid dapat bertambah banyak.

\section{METODE}

Metode Pelaksanaan Pengabdian kepada Masyarakat dilaksanakan dengan tahapan sebagai berikut :

a. Tahap Persiapan

Tahap persiapan dilakukan untuk melakukan diskusi dengan Takmir Masjid Nurrulloh dan tokoh-tokoh masyarakat setempat tentang rencana pelaksanaan pengabdian masyarakat oleh tim Dosen Fakultas Teknik UTP Surakarta. Dari diskusi tersebut diharapkan akan diperoleh informasi secara benar. Diskusi tersebut juga berguna untuk menentukan langkah berikutnya demi terwujudnya kondisi yang diharapkan. Juga mulai direncanakan langkah aplikasi pengambilan data di lapangan berikut koordinasi dengan perangkat kelurahan terkait otoritas wilayah berada di perangkat kelurahan Mojosongo. Posisi tim pengabdian masyarakat Dosen hanya sebagai konsultan yang tidak mempunyai kewenangan memutuskan. Otoritas tim pengabdian masyarakat Dosen hanya memberikan saran dan usulan yang bersifat membangun dalam koridor rasional dan terukur.

b. Tahap Pelaksanaan

Adapun tahap pelaksanaan pada kegiatan yang akan dilaksanakan pada tahap ini adalah:

1. Melakukan kompilasi data pengukuran, dokumentasi foto, dan lain-lain sebagai bahan untuk proses analisis.

2. Melakukan analisis tapak terhadap kondisi tapak lokasi masjid Nurrulloh.

3. Melakukan analisis ruang yang sesuai dengan kebutuhan.

4. Membuat gambar pra-desain berupa gambar site-plan, denah dan perspektif.

5. Dari bahan pra-desain yang telah disusun, dilakukan diskusi dengan takmir masjid, tokoh masyarakat dan jamaah untuk mendapatkan masukan dan saran untuk perbaikan pradesain.

6. Setelah mendapat persetujuan gambar pra-desain maka dibuat perhitungan struktur gambar detailnya untuk gambar pelaksanaan konstruksi.

7. Penyusunan gambar detail untuk pelaksanaan konstruksi.

8. Penyusunan analisa yang diperlukan sebagai pendukung.

9. Penyusunan perkiraan rencana anggaran biayanya (RAB).

Kerjasama yang baik antara Takmir masjid Nurrulloh dengan Tim Pengabdian UTP Surakarta, mampu memecahkan permasalahan yang dihadapi warga kampung Ngemplak RT.02 RW.29 Mojosongo, Jebres, Surakarta terkait kapasitas masjid yang sudah tidak mampu 
menampung jamaah. Masjid yang ada direncanakan untuk direnovasi menjadi dua lantai, sehingga kapasitasnya bertambah. Gambar dan RAB yang sudah direncanakan akan menjadi acuan didalam pembangunan kedepan. Dengan adanya gambar dan RAB memberikan kepercayaan masyarakat didalam penggalangan dana untuk tahap pelaksanaan renovasi masjid. Tingkat kepercayaan yang tinggi jamaah/masyarakat akan memudahkan Takmir didalam penggalangan dana baik di internal maupun eksternal masyarakat.

\section{HASIL DAN PEMBAHASAN}

Memperhatikan permasalahan diatas, maka dibutuhkan pendampingan oleh ahli desain bangunan, struktur bangunan dan estimasi biaya (arsitek, ahli struktur dan estimator). Selain itu juga membutuhkan orang yang berpengalaman dan memiliki latar belakang pengetahuan di bidang Arsitektur Islam (Masjid) dan mengerti nilai-nilai Islam.

Membangun masjid penuh maslahat adalah sebaik-baik ibadah. Maka kerja membangun masjid hanyalah urusan kita dengan Allah Subhanahuwata'ala. Jika masjid infrastrukturnya baik, nyaman untuk ibadah, maka mudah-mudahan akan banyak hamba Allah yang makin khusyuk beribadah. Jika masjid banyak menyediakan layanan ta'lim, belajar Qur'an, maka mudah-mudahan jamaah makin dekat dengan Allah. Jika masjid dapat menjawab permasalahan sosial, memudahkan mencari pekerjaan, memudahkan seseorang mendapatkan jodoh, menjembatani potensi ekonomi sehingga terjadi pemberdayaan, maka mudah-mudahan makin banyak yang ke masjid. Lalu janji Rasulullah, barangsiapa menjadi jalan kebaikan, baginya pahala yang sama ketika kebaikan itu dilakukan. Bayangkan saja pahala yang didapat para aktivis masjid. Inilah tujuan kita: keridhoan Allah semata. Niat membangun masjid harus lurus selurus-lurusnya. Dilakukan hanya untuk ridho Allah. Dikerjakan untuk menghapus dosa dan salah di masa lalu. Diniatkan untuk menjadi kebaikan yang mengalir untuk kedua orang tua kita. Niat lurus para pengurus masjid akan memudahkan proses dan langkah masjid dalam pembangunan kedepannya. Baik pembangunan fisik maupun non fisik.

Renovasi peningkatan kapasitas pada masjid dari satu lantai menjadi dua lantai dilakukan karena jumlah jamaah pada waktu sholat selalu melebihi kapasitas yang tersedia. Pada renovasi ini dilakukan jenis renovasi berat dikarenakan perubahan struktur bangunan, perubahan bentuk atap, dan tata letak bangunan sehingga membutuhkan biaya yang besar. pada saat melakukan perencanaan diperlukan ketepatan dalam menghitung biaya renovasi. Pada saat perhitungan tidak tepat menyebabkan proses renovasi tertunda.

Tim pendampingan/pengabdian dari program studi Arsitektur dan Teknik Sipil, Universitas Tunas Pembangunan berusaha semaksimal mungkin untuk perencanaan gambar dan perhitungan RAB masjid Nurrulloh. Berdasarkan analisis dari tim pengabdian, bahwa apabila gambar sudah direncanakan dengan matang dan penampilan bangunan yang baik maka akan mempengaruhi kepercayaan masyarakat dan umat Islam secara umum terhadap rencana renovasi masjid ini. Kemudian perhitungan biaya yang telah dihitung dengan analisa yang standart dan ilmiah, maka kepercayaan masyarakat akan semakin bertambah tinggi. Besarnya biaya pembangunan yang sudah dihitung, maka akan memberi kemudahan didalam merencanakan tahap berikutnya, yaitu tahap pembangunan.

Pertimbangan utama didalam merenovasi bangunan masjid ini adalah untuk meningkatkan jumlah atau kapasitas masjid. Kapasitas masjid ini akan bisa dilipatkan jumlahnya, apabila dibangun menjadi 2 (dua) lantai. Dengan dibangunnya masjid menjadi dua lantai, selain kapasitas jamaah bisa bertambah, juga tersedianya ruang-ruang pendukung masjid. Selain itu kawasan masjid menjadi lebih teratur dan rapai. Hubungan ruang dan 
sirkulasi juga teratur dan nyaman. Berikut hasil desain renovasi masjid dan perhitungan biaya (RAB) untuk renovasi masjid Nurrulloh:
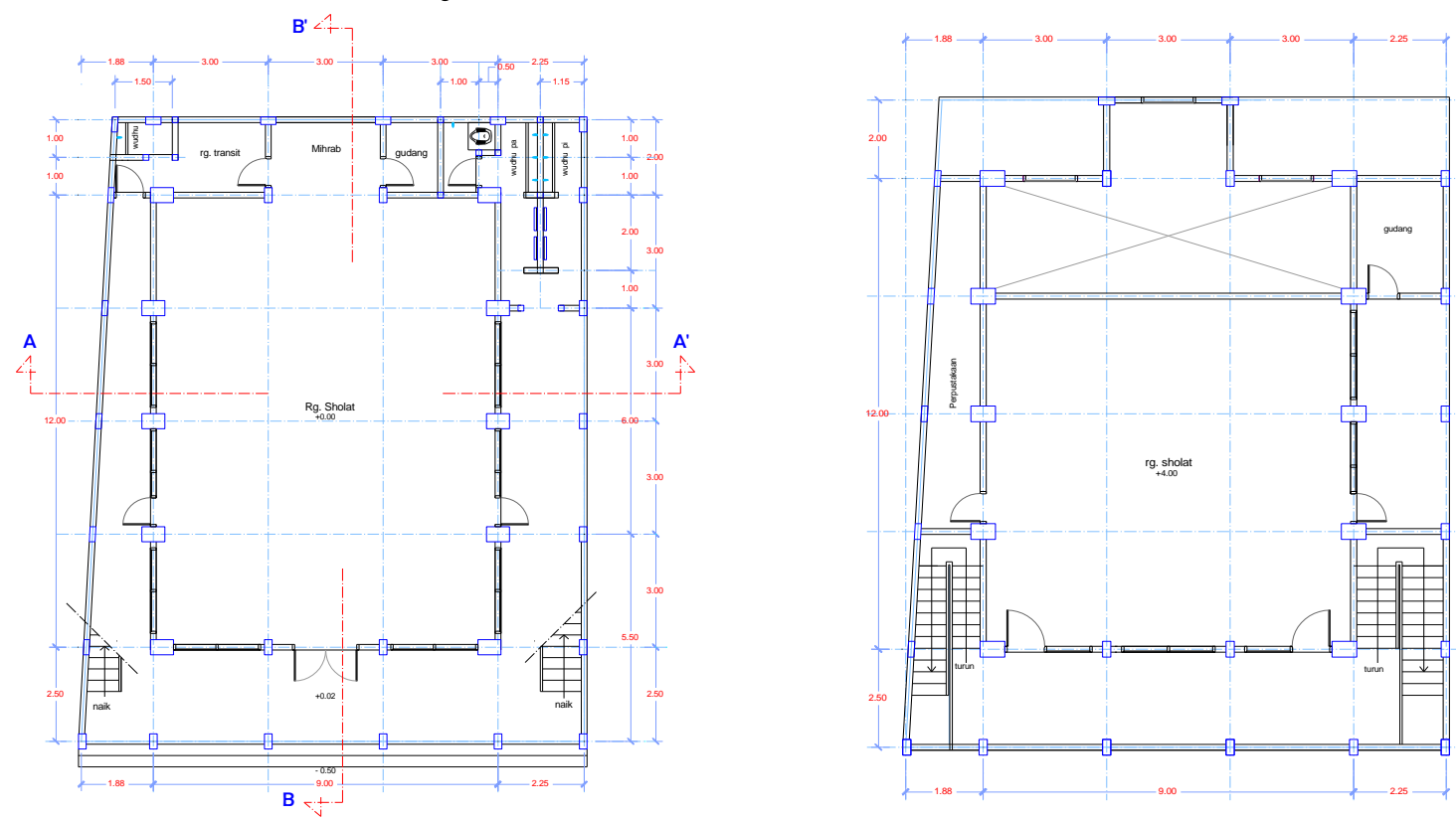

Gambar 4. Denah Lantai 1 dan 2 Masjid Nurulloh
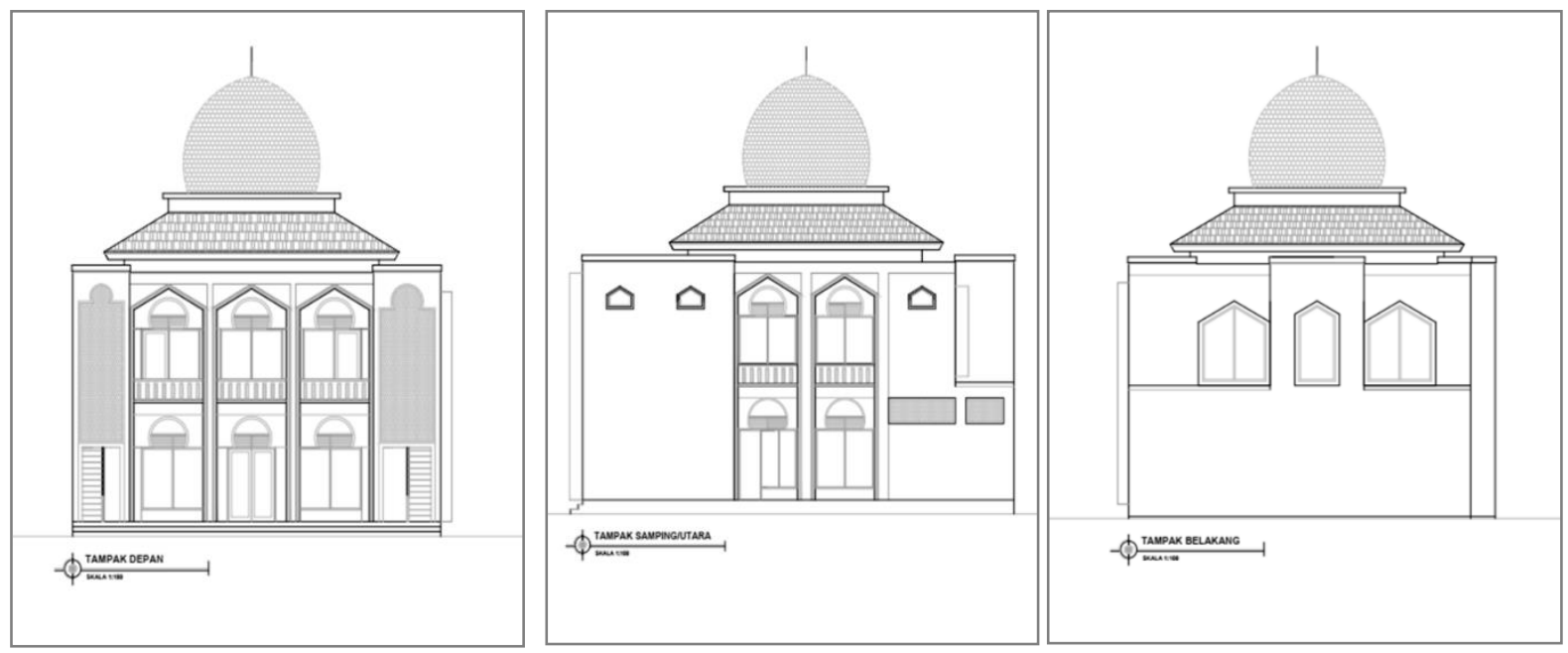

Gambar 5. Tampak Depan, Samping dan Belakang Masjid Nurulloh

Bahwa penampilan renovasi Masjid Nurrulloh mengambil bentuk lokal dan modern, yang tercermin pada bentuk atap bangunan. Bentuk limasan mengadopsi bentuk atap dari rumah di sekitar masjid, sedangkan kubahnya yang terbuat dari Galvanis yang diberi motif dari enamel. Adapun konsep pencahayaan dan penghawaan memanfaatkan sinar matahari dan hembusan angin yang masih cukup. Material finishing ornamen menggunakan material GRC yang cukup ringan, namun tahan panas dan air. Berikut penampilan bangunan Masjid Nurrulloh secara 3D (tiga dimensi): 

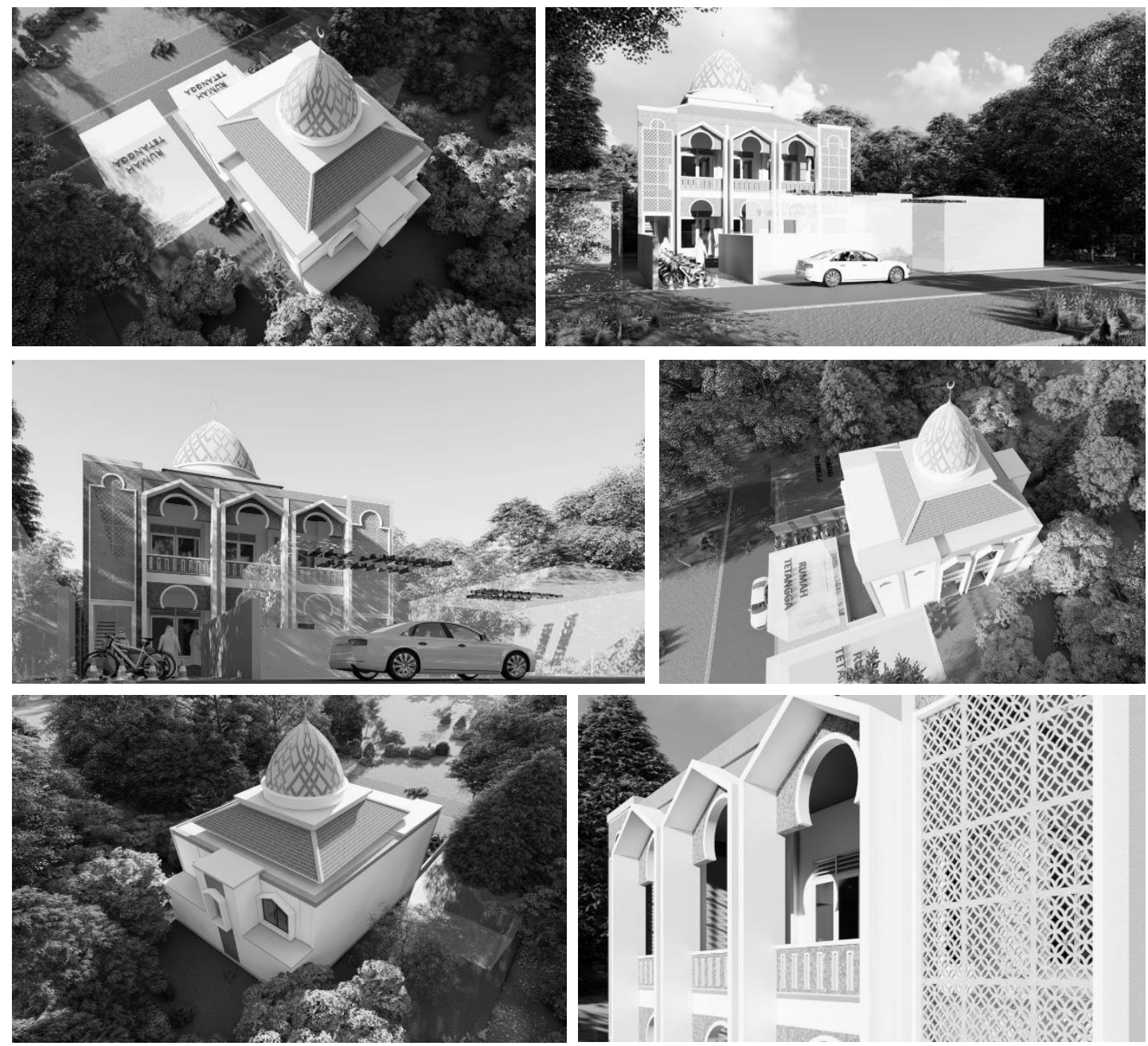

Gambar 6. Tampak Gambar 3D Masjid Nurulloh

Setelah desain gambar selesai dibuat, maka langkah selanjutnya Tim Pengabdian UTP Surakarta yang juga terdiri dari dosen program studi Teknik Sipil akan menghitung Rencana Anggaran dan Biaya (RAB). RAB dihitung berdasarkan volume pekerjaan mulai dari pekerjaan persiapan hingga pekerjaan finishing renovasi masjid Nurrulloh. Penghitungan $\mathrm{RAB}$ dimulai dari perhitungan volume pekerjaan, kemudian menyusun analisis pekerjaan yang sesuai dengan item pekerjaan mengacu pada analisis harga upah dan bahan yang dikeluarkan oleh pemerintah kota Surakarta. Tim pengabdian telah menyelasaikan pendampingan didalam perencanaan Gambar dan RAB masjid Nurrulloh yang direncanakan menjadi dua lanta, yang membutuhkan dana \pm Rp. 1.500.000.000,00. Adapun biaya/dana renovasi masjid yang akan dilaksanakan bersumber dari swadaya masyarakat setempat. Takmir Masjid berencana menghimpun dana, dengan membuat proposal bantuan dana kepada semua masyarakat kampung Ngemplak RT.02 RW.29 Mojosongo, Surakarta. Selain warga setempat, penggalangan dana juga akan disampaikan kepada semua kaum Muslimin di kota Surakarta dan sekitarnya. Harapanya dana yang ada sekarang ditambah dengan hasil penggalangan dana, pembangunan masjid segera terealisasi. Kehadiran tim pengabdian yang telah menghasilkan gambar kerja dan perhitungan RAB sangat berguna untuk perijinan pembangunan dan penggalangan dana. Adanya gambar dan RAB yang dihitung secara ilmiah memberikan kepercayaan yang besar kepada masyarakat luas, khususnya kampung Ngemplak 
RT.02 RW.29. Berikut penulis sampaikan rekapitulasi RAB untuk renovasi masjid Nurrulloh menjadi dua lantai:

Tabel 1. Rekapitulasi Rencana Anggaran dan Biaya

\begin{tabular}{|c|c|c|}
\hline \multicolumn{3}{|c|}{$\begin{array}{l}\text { REKAPITULASI } \\
\end{array}$} \\
\hline \multicolumn{3}{|c|}{ RENCANA ANGGARAN BIAYA (RAB) } \\
\hline \multirow{3}{*}{$\begin{array}{l}\text { PEKERJAAN } \\
\text { LOKASI } \\
\text { TAHUN ANGGARAN }\end{array}$} & \multirow{3}{*}{\multicolumn{2}{|c|}{$\begin{array}{l}\text { : PEMBANGUNAN MASJID NURRULLOH } \\
: \text { KEL.MOJOSONGO KEC. JEBRES KOTA SURAKARTA } \\
: 2021\end{array}$}} \\
\hline & & \\
\hline & & \\
\hline NO & URAIAN PEKERJAAN & $\begin{array}{l}\text { JUMLAH } \\
\text { HARGA } \\
\text { ( Rp. })\end{array}$ \\
\hline 1 & 2 & 3 \\
\hline I. & PEKERJAAN PERSIAPAN & $6.700 .000,00$ \\
\hline II. & PEKERJAAN FISIK MASJID LANTAI 1 & \\
\hline A. & PEKERJAAN TANAH & $14.969 .881,84$ \\
\hline B. & PEKERJAAN PONDASI & $162.798 .764,30$ \\
\hline C. & PEKERJAAN BETON & $360.249 .402,96$ \\
\hline D. & PEKERJAAN DINDING PLESTERAN DAN ARCHITECTURE & $106.208 .852,32$ \\
\hline E. & PEKERJAAN PENUTUP LANTAI DAN DINDING & $114.434 .581,31$ \\
\hline $\mathrm{F}$. & PEKERJAAN LANGIT-LANGIT & $43.654 .103,15$ \\
\hline G. & PEKERJAAN PINTU DAN JENDELA & $55.761 .070,59$ \\
\hline H. & PEKERJAAN PENGECATAN & $19.446 .327,55$ \\
\hline I. & PEKERJAAN INSTALASI LISTRIK & $4.255 .460,00$ \\
\hline J. & PEKERJAAN INSTALASI AIR & $9.868 .804,64$ \\
\hline & JUMLAH PEKERJAAN LANTAI 1 & 891.647.248,65 \\
\hline III. & PEKERJAAN FISIK MASJID LANTAI 2 & \\
\hline A. & PEKERJAAN BETON & $265.811 .205,52$ \\
\hline B. & PEKERJAAN DINDING PLESTERAN DAN ARCHITECTURE & $105.347 .411,75$ \\
\hline C. & PEKERJAAN PENUTUP LANTAI DAN DINDING & $62.141 .902,15$ \\
\hline D. & PEKERJAAN ATAP DAN LANGIT-LANGIT & $133.212 .468,83$ \\
\hline E. & PEKERJAAN PINTU DAN JENDELA & $47.343 .239,55$ \\
\hline $\mathrm{F}$. & PEKERJAAN PENGECATAN & $17.714 .967,30$ \\
\hline G. & PEKERJAAN INSTALASI LISTRIK & $5.856 .040,00$ \\
\hline H. & PEKERJAAN INSTALASI AIR & $4.824 .288,00$ \\
\hline & JUMLAH PEKERJAAN LANTAI 2 & 642.251.523,12 \\
\hline & JUMLAH TOTAL & 1.540.598.771,77 \\
\hline & DIBULATKAN & 1.540.598.000,00 \\
\hline & Satu milyar lima ratus empat pul uh juta lima ratus semb & apan ribu rupiah \\
\hline
\end{tabular}

\section{KESIMPULAN}

Kerjasama antara Takmir Masjid Nurrulloh dengan Tim Pengabdian UTP Surakarta menghasilkan desain, gambar kerja dan perhitungan RAB sebagai jawaban permasalahan yang dihadapi oleh masyarakat kampung Ngemplak RT.01 RW.29 terkait kapasitas masjid yang sudah tidak mampu menampung jamaah masyarakat kampung Ngemplak dan sekitarnya. Gambar dan RAB yang sudah disusun bersama menjadi acuan takmir dan masyarakat didalam rencana renovasi masjid yang akan dilaksanakan. Adanya gambar dan RAB juga berdampak kepada kepercayaan dan semangat masyarakat didalam penggalangan dana yang akan digunakan didalam renovasi masjid. 


\section{UCAPAN TERIMA KASIH}

Ucapan terimakasih kami sampaikan terhadap Takmir Masjid Nurrulloh, atas kerjasama yang saling menguntungkan. Penulis juga menyampaikan terimakasih kepada UTP Surakarta yang telah memberikan dana hibah pengabdian, sehingga kami bisa menjalankan pengabdian kepada masyarakat sebagai perwujudan tri dharma perguruan tinggi.

\section{DAFTAR PUSTAKA}

Abdzar, M. 2012. Revitalisasi Peran Masjid Sebagai Basis Dan Media Dakwah Kontemporer, Jurnal Dakwah Tabligh. 13 (1), hlm. 109-121.

Arti Musholla. 2016. diakses pada http://kajiantentangquran.blogspot. com/2016/05/artimushola.html

Aziz Toriq, Widajanti Andjar. 2018. Komparasi Ergonomi Ruang Wudhu Masjid Jami' AlKarim Pesanggrahan dan Masjid Ash Shaff Emerald Bintaro. Vitruvian. p-ISSN : 2088-8201 eISSN : 2598-2982.

Dalmeri. 2014. Revitalisasi fungsi masjid sebagai pusat ekonomi dan dakwah multikultural. Walisongo. 22 (2), hlm. 321-350

Hasibuan, Malayu S.P. 2012. Manajemen Sumber Daya Manusia, cetakan keenam belas. Jakarta: PT Bumi Aksara.

Neufert, Ernst. Terjemahan oleh Dr. Ing Sunarto Tjahjadi dan Ferryanto Chaidir. Data Arsitek Jilid 1 Edisi 33. Jakarta. Erlangga. ISBN 979-411-307- 7.

Nurmianto, Eko. 2004. Ergonomi Konsep Dasar Dan Aplikasinya. Surabaya: Guna Widya. Panero dan Zelnik. 2003. Dimensi Manusia \& Ruang Interior. Jakarta: Erlangga.

Prasetyo, W. Bagas, 2000. Evaluasi Ergonomi dalam Desain. Surabaya: Proceeding Seminar Nasional Ergonomi, Jurusan TI - ITS.

Rochmat, A.M. 2018. Melihat Bentuk Awal Masjid Nabawi. NU Online. Diakses dari https://islam.nu.or.id/post/read/90947/melihat-bentuk-awal-masjid-nabawi

Sutrisno, Edi. 2009. Manajemen Sumber Daya Manusia Edisi Pertama. Jakarta : Kencana Prenada Media Group.

SNI 03-6575-2001 Tata Pencahayaan Buatan Gedung Tahun 2001.

Widodo, Eko. Suparno. 2015. Manajemen Pengembangan Sumber Daya Manusia. Cetakan I. Yogyakarta:Pustaka Pelajar.

Wulandari, Henny. 2014. Eksplorasi Pengalaman Panca Indera Untuk Perancangan Interior. Dimensi Interior, 12, No. 2, 85-90

Wrihatnolo, Randy R. dan R.N, Dwidjowijoto. 2007. Manajemen Pemberdayaan: Sebuah Pengantar dan Panduan untuk Pemberdayaan Masyarakat. Jakarta: Elex Media Komputindo. 